\title{
Effects of Escherichia coli Hemolysin on Human Monocytes Cytocidal Action and Stimulation of Interleukin 1 Release
}

Sucharit Bhakdi," Marion Muhly," Stephan Korom," and Günter Schmidt ${ }^{\star}$

*Institute of Medical Microbiology, University of Mainz, D-6500 Mainz; ${ }^{\ddagger}$ Institute of Experimental Biology and Medicine, D-2061 Borstel, Federal Republic of Germany

\begin{abstract}
This study reports on the potent cytocidal and interleukin-1 releasing properties of Escherichia coli hemolysin (ECH) on human monocytes. Nanomolar concentrations of purified ECH $(250-2,000 \mathrm{ng} / \mathrm{ml})$ caused rapid and irreversible depletion of cellular ATP to levels below $20 \%$ of controls within $60 \mathrm{~min}$. Subcytocidal doses (10-200 $\mathrm{ng} / \mathrm{ml})$ of ECH induced rapid release within 60-120 min of large amounts of interleukin $1 \beta$ $(I L-1 \beta)$ from cultured monocytes. IL-1 $\beta$ release occurred in the presence of actinomycin $D$ and cycloheximide, and was thus probably due to processing and export of intracellular IL-1 $\beta$ precursor. Incubation of toxin-producing $E$. coli at ratios of only 0.3-3 colony-forming units per monocyte evoked $\sim 50 \%$ depletion of total cellular ATP within 90 min. Toxin producers also stimulated synthesis and release of large amounts of interleukin 1 , but not of tumor necrosis factor within the same time span. In contrast, non-toxin producers caused neither cell death nor rapid interleukin 1 release. Stimulation of rapid interleukin 1 release coupled with potent cytocidal effects on cells of monocytic origin may represent pathogenetically significant events incurred by bacterial strains that produce ECH and related cytolysins. (J. Clin. Invest. 1990. 85:1746-1753.) cytolysin • membrane permeabilization • cytokine processing
\end{abstract}

\section{Introduction}

Escherichia coli hemolysin $(\mathrm{ECH})^{1}$ is produced by approximately $50 \%$ of $E$. coli isolates causing extraintestinal infections in man, and is thus one of the most prevalent bacterial protein toxins encountered by humans (1-7). The pathogenetic relevance of $\mathrm{ECH}$ has been established in several animal models (8-10). The cytolysin has recently been identified as a novel prototype of a pore-forming protein that may insert as a monomer into target lipid bilayers to generate a functional transmembrane lesion of 1-2 nm effective diameter (11-14). The cytolysins of Proteus, Morganella, and Pasteurella haemolytica exhibit marked structural homologies with $\mathrm{ECH}$, and probably constitute a toxin family sharing similar functional and immunological properties (15-18).

Address reprint requests to Dr. Bhakdi, Institute of Medical Microbiology, University of Mainz, D-6500 Mainz, FRG.

Received for publication 5 June 1989 and in revised form 30 December 1990.

1. Abbreviations used in this paper: ECH, E. coli hemolysin; LPS, lipopolysaccharide; NHS, normal human serum; PMB, polymyxin B.

J. Clin. Invest.

(c) The American Society for Clinical Investigation, Inc. 0021-9738/90/06/1746/08 \$2.00

Volume 85, June 1990, 1746-1753
A deeper understanding of the mechanisms responsible for the pathogenetic role of any bacterial cytolysin requires resolution of two basic questions. First, cells that represent targets for toxin attack under physiological conditions must be identified. Second, the major consequences of toxin attack on these cells should be recognized. In vitro, bacterial cytolysins will generally damage a broad spectrum of mammalian cells as well as artificial lipid bilayers (14). However, this does not mean that they will mount an unselective attack on all cells they encounter in the host organism. On the one hand, certain cell types may possess high-affinity binding sites and thus be particularly vulnerable. On the other hand, naturally occurring antibodies and lipoproteins generally exhibit the capacity to neutralize membrane-damaging cytolysins. Successful attack thus requires that toxin-binding membrane perturbation occur more rapidly than the inactivation processes. For these reasons, we are conducting model studies on the cytotoxic action of several major pore-forming bacterial cytolysins on human cells in the presence of plasma proteins. First results obtained with $S$. aureus $\alpha$-toxin and ECH revealed an unexpected divergence in their action. Although both toxins attack proteinfree liposomes and planar lipid bilayers to produce transmembrane pores of similar size, $\alpha$-toxin mounted a selective attack on blood platelets (19), whereas ECH exhibited potent cytocidal action towards granulocytes (20). Despite their classical designation as hemolysins, neither toxin induced lysis of human erythrocytes unless applied at extremely high concentrations.

We have now investigated the action of ECH on monocytes utilizing purified, LPS-depleted $\mathrm{ECH}$, as well as a series of $E$. coli strains. The results extend brief earlier reports (21, 22) and demonstrate that ECH displays a high cytocidal potency towards monocytes. In addition, toxin attack induces very rapid release of Il- $1 \beta$ from cultured cells and from cells confronted with viable $E$. coli. Release of IL- $1 \beta$ by cells of monocytic origin following attack by very low doses of ECH and, probably, other members of this toxin family could contribute significantly to the pathogenesis of local and systemic lesions during gram-negative infections.

\section{Methods}

Preparation of ECH. A detailed description of the procedure for isolating ECH in lipopolysaccharide (LPS)-depleted form from culture supernatants of $E$. coli strain LE $2001(23,24)$ is to be given separately (Muhly, M., U. Zähringer, and S. Bhakdi, manuscript in preparation), and only the major steps will briefly be recounted here. $200 \mathrm{ml}$ of prewarmed Todd-Hewitt-Broth (THB; Difco Laboratories, Detroit, MI) supplemented with $15 \mathrm{mM} \mathrm{CaCl}_{2}$ were inoculated with $1 \mathrm{ml}$ of an overnight bacterial culture and maintained at $37^{\circ} \mathrm{C}$ for $\sim 3 \mathrm{~h}$ until the $\mathrm{pH}$ of the culture dropped to 6.0-6.1. Cells were pelleted by centrifugation (5 min, 25,000 g, Sorvall centrifuge RC 2B, rotor SS 34; Sorvall Instruments Div. Du Pont Co., Newton, CT) and to the supernatants 
were added $22 \mathrm{~g}$ polyethyleneglycol 4000 (PEG) per $100 \mathrm{ml}$ fluid. After stirring for $20 \mathrm{~min}, 4^{\circ} \mathrm{C}$, the PEG precipitates were collected by centrifugation, dissolved in $5 \mathrm{ml}$ of distilled water, and sterile filtered. The filtered toxin solutions were subjected to a 60 min centrifugation in linear $10-50 \% \mathrm{wt} / \mathrm{vol}$ glycerol density gradients using a vertical rotor type VTi 65.1 (Beckman Instruments, Inc., Fullerton, CA). Fractions exhibiting peak hemolytic activity $(2,000-4,000 \mathrm{HU} / \mathrm{ml})$ and containing nonaggregated, LPS-depleted toxin were pooled and used in the experiments. The preparations contained $300-400 \mu \mathrm{g} / \mathrm{ml}$ protein as determined by amino acid analyses and ELISA, and $1-1.5 \mu \mathrm{g} / \mathrm{ml} \mathrm{LPS}$ as determined with a Limulus assay (KabiVitrum Diagnostica, Stockholm, Sweden). The toxin was stored in aliquots at $-70^{\circ} \mathrm{C}$ and fully retained its cytolytic activity for $>3 \mathrm{mo}$. For control experiments, $\mathrm{ECH}$ was inactivated by heating at $56^{\circ} \mathrm{C}$ for $60 \mathrm{~min}$.

\section{Genetically related $E$. coli strains}

$E$. coli 2980 and derivatives thereof were used in this study. E. coli 2980 of serotype 018A:K5:H5 produced mannose-resistant P-fimbriae of serotype F8 and mannose-sensitive type 1 fimbriae (now termed F1). The strains and the properties relevant here are listed in Table I.

E. coli 20397 ( $\mathrm{F8}^{-}$), a mutant lacking the P-fimbriae was obtained by mutagenesis of strain $2980(25)$. E. coli $20469\left(\mathrm{Hly}^{-}\right)$was a spontaneous hemolysin-negative mutant of strain 2980 . The capsule-negative $\left(\mathrm{K5}^{-}\right)$strains 20400 and B2313 were selected from the parents 20397 and 20469, respectively, as mutants resistant to coliphage $K 5$ which is specific for the K5 antigen (26).

In addition, an $r f b$ defective mutant having the complete LPS core but unable to produce $O$-specific polysaccharides was obtained by introduction of the his-linked defective $r f b$ region of an $E$. coli K-12 Hfr donor into $E$. coli 2980 . The rough strain B2249 $\left(018 \mathrm{~A}^{-}: \mathrm{K5}^{-}\right)$was selected therefrom as a mutant resistant to coliphage $\mathrm{K} 5$.

All the strains listed in Table I still produced the F1 fimbriae which have been shown to play a role in adherence to rat peritoneal macrophages and human polymorphonuclear granulocytes (27).

Other reagents. LPS were from two sources. First, we used preparations of active or inactive ECH containing the measured amounts of LPS. Second, LPS from $E$. coli 055:B5 were obtained from Sigma (Münich, FRG) and suspended in sterile saline at $10 \mathrm{mg} / \mathrm{ml}$. Polymyxin B (PMB) was obtained from Serva (Heidelberg, FRG) and used in cell cultures at a final concentration of $2 \mu \mathrm{g} / \mathrm{ml}$. All buffer solutions were autoclaved before use. Normal human serum (NHS) was obtained from the respective donors and used immediately or stored at $-20^{\circ} \mathrm{C}$ for no longer than $7 \mathrm{~d}$. Three NHS samples were depleted of IgG by one passage over a 1-ml protein G-Sepharose column (Pharmacia, Uppsala, Sweden, equilibrated in saline). Over 95\% IgG was removed as ascertained by radial immunodiffusion. Pooled human IgG was obtained from Sandoz Laboratories (Basel, Switzerland).

\section{Preparation of monocytes}

Blood was drawn in heparin $(50 \mathrm{U} / \mathrm{ml}$ final concentration; obtained from Hoffmann-La Roche, Basel, Switzerland) and 5-ml aliquots were applied to $4 \mathrm{ml}$ Ficoll-Hypaque gradients (Pharmacia Fine Chemicals) in sterile plastic tubes. After $45 \mathrm{~min}$ centrifugation at $900 \mathrm{~g}, 20^{\circ} \mathrm{C}$ (Heraeus Minifuge RF; Hereens Sepatech GmbH, Ostende, FRG) cells

Table I. E. coli Strains and Relevant Properties

\begin{tabular}{lcccr}
\hline Strain No. & 018A & K5 & F8 & Hly \\
\hline 2980 & $+^{*}$ & + & + & + \\
20397 & + & + & - & + \\
20400 & + & - & - & + \\
20469 & + & + & + & - \\
B2313 & + & - & + & - \\
B2249 & - & - & + & +
\end{tabular}

*+, present; -, absent from the intermediate phase were recovered, washed twice with RPMI medium at $500 \mathrm{~g}$ for $5 \mathrm{~min}\left(20^{\circ} \mathrm{C}\right)$, and resuspended in $8 \mathrm{ml}$ of this buffer. 200- $\mu \mathrm{l}$ aliquots were applied to 96-well culture plates (Nunc, Wiesbaden, FRG) for $1 \mathrm{~h}$ in an incubator $\left(7 \% \mathrm{CO}_{2}, 37^{\circ} \mathrm{C}\right)$. Thereafter, one of two protocols was followed. To obtain highly purified monocytes, the supernatants containing nonadherent cells were aspirated, and the plates were thoroughly washed by three consecutive applications of $200 \mu \mathrm{l}$ RPMI. The buffer was applied under vigorous pressure using a 12-channel distributor. Alternatively, the supernatants were aspirated and adherent cells were used without further washing. The latter procedure permitted considerably higher recovery of monocytes that were contaminated with lymphocytes and platelets. Since both types of cell preparations yielded similar results with respect to IL- $1 \beta$ responses, most experiments were performed following the second protocol. Cell numbers were approximated by counting 25 fields per well through a calibrated microscopic objective. Each culture well typically contained approximately $10^{5}$ monocytes in routine experiments (without thorough washing). Monocytes were identified by staining for nonspecific esterase and they typically accounted for $\sim 50 \%$ of total cells. Vigorous washing resulted in monocyte preparations that were 90-95\% pure, but cell numbers were then in the order of $1.5-2 \times 10^{4}$ per well.

The adherent monocytes were either used directly, or they were cultured overnight in RPMI containing $10 \%$ FCS, $0.1 \mathrm{mg} / \mathrm{ml}$ streptomycin and $100 \mathrm{U} / \mathrm{ml}$ penicillin (without PMB) and used on the following day. When indicated, cycloheximide or actinomycin $\mathrm{D}$ was added to the medium at a final concentration of 2 or $10 \mu \mathrm{g} / \mathrm{ml}$, respectively.

\section{Treatment of monocytes with stimuli}

The supernatants were aspirated and cells were immersed in $100 \mu \mathrm{l}$ of either $10 \%$ FCS or $10 \%$ autologous serum in RPMI 1640 medium (Biochrom, Berlin, FRG). $10 \mu$ of appropriately diluted LPS or ECH were then added to yield the required final concentration of each stimulus. Incubations with LPS were for 2,6 , and $24 \mathrm{~h}$. Incubation periods with ECH varied between minutes and $24 \mathrm{~h}$, as described in the individual experiments. PMB was added at a final concentration of 2 $\mu \mathrm{g} / \mathrm{ml}$ whenever indicated.

Experiments with genetically related strains of $E$. coli were conducted as follows. Bacteria from overnight cultures were inoculated into fresh broth and brought into log-phase growth by culture for 3-31/2 $h$ at $37^{\circ} \mathrm{C}$. The cells were then pelleted (Eppendorf table-top centrifuge, $10,000 \mathrm{~g}, 2 \mathrm{~min}$ ), washed twice with sterile saline, and suspended to approximately $3 \times 10^{8} \mathrm{CFU} / \mathrm{ml}$ in PBS. No free toxin was detectable by functional or immunoassays. Cell dilutions were prepared from these stock suspensions and added to RPMI/10\% FCS to yield the final, required ratios of bacteria to monocytes $(0.03,0.3,3,30$, and 300 $\mathrm{CFU} /$ monocyte). After $90 \mathrm{~min}, 37^{\circ} \mathrm{C}$, supernatants were harvested and given $10 \mu \mathrm{g} / \mathrm{ml}$ PMB to halt bacterial growth. Hemolytically active toxin was never detectable in any of these supernatants.

Measurements of cellular ATP. At the end of the incubation periods, cell supernatants were collected and the microculture dishes were placed on ice. Measurements of cellular ATP were performed by lysing the cells with $0.2 \mathrm{ml}$ of ice-cold $0.1 \%$ (vol/vol) Triton X-100 (aqueous solution) and pipetting 70-100 $\mu \mathrm{l}$ of the solubilisate into a prewarmed $\left(2 \mathrm{~min}, 37^{\circ} \mathrm{C}\right) \mathrm{mix}$ of firefly reagent (ATP-bioluminescence CLS from Boehringer, Mannheim, FRG; $100 \mu \mathrm{l}$ ) plus $200 \mu \mathrm{l}$ PBS. Bioluminescence measurements were performed using a LumiAggro-Meter (model 400; Chrono-Log Corp., Coulter Electronics, Krefeld, FRG). These ATP-measurements proved sensitive, rapid, and reliable. The cellular ATP content ranged from 70 to $160 \mathrm{pmol} / \mathrm{well}$, dependent on donor and cell preparation. The relative bioluminescence peaks determined for the control cultures (without toxin) were taken as $100 \%$ values for each series. The heights of the bioluminescence peaks varied linearly with the amount of ATP in a given sample. Bacterial ATP was not detected with the described assay. Control assays conducted with ATP (from Boehringer) excluded that ECH or a product of its interaction with monocytes interfered with the luciferase assay. 
Measurements of monokines. IL- $1 \beta$ and TNF- $\alpha$ were assayed in cell culture supernatants with the use of radioassays (obtained from IRE Diagnostics, Düsseldorf, FRG). Additionally, IL-1 $\beta$ determinations were also performed with the use of an ELISA from Paesel (Frankfurt, FRG). Both assays yielded equivalent results. Concentrations were expressed in nanograms per milliliter and calculated from calibration curves obtained with the standards supplied in each kit. In three experiments, attempts were also made to measure intracellular IL-1 $\beta$. After removal of the cell supernatants, cell adhering to the culture dishes were immersed in PBS and lysed by three cycles of freeze-thawing. These samples were then analyzed by radioimmunoassay and ELISA.

\section{Results}

Release of monokines in response to LPS. Although the ECH preparations utilized in this study contained less than $1 \mathrm{~mol}$ LPS per 40 mol cytolysin, it was essential to exclude that any detected monokine-releasing effects might derive from contaminating endotoxin. The production of monokines in response to LPS-stimulation of monocytes was therefore first studied and the following observations were made. First, it was found that freshly isolated monocytes responded to LPS at a concentration threshold of $\sim 1 \mathrm{ng} / \mathrm{ml}$ with the production of large amounts of TNF- $\alpha$ and IL- $1 \beta$. The levels of TNF- $\alpha$ measured after an incubation of $6 \mathrm{~h}$ generally was in the order of $25-30 \mathrm{ng} / \mathrm{ml}$ cell supernatant. The levels of IL- $1 \beta$ remained stationary $2 \mathrm{~h}$ after addition of LPS, and then rose markedly to reach levels of $\sim 15-20 \mathrm{ng} / \mathrm{ml}$ after $6 \mathrm{~h}$ incubation (Fig. 1). These results were in good accord with published data (28). The addition of $2 \mu \mathrm{g} / \mathrm{ml}$ PMB to cell cultures almost totally inhibited the cytokine-stimulatory action of $1 \mathrm{ng} / \mathrm{ml}$, but suppressed to a lesser extent the effect of $10 \mathrm{ng} / \mathrm{ml}$ (Fig. 1). The addition of LPS to cell cultures did not evoke any depletion of cellular ATP.

Adherent monocytes that had been cultured overnight presented an entirely different response to LPS, irrespective of the source of endotoxin. These cells continued to exhibit an essentially identical dose-response behavior with respect to production of TNF- $\alpha$. However, the IL- $1 \beta$ response dropped to levels essentially indistinguishable from background and no significant IL- $1 \beta$ production could be elicited even with very high doses of LPS (Fig. 1). These results corroborated a recent

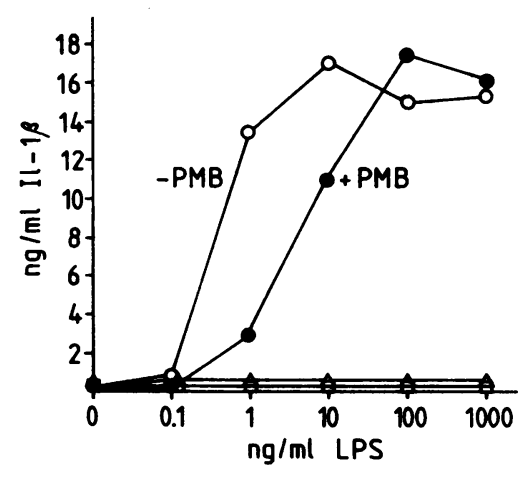

Figure 1. Production of IL $-1 \beta$ by freshly isolated human monocytes (circles) or cultured monocytes (triangles) in the presence or absence of 2 $\mu \mathrm{g} / \mathrm{ml}$ PMB induced by LPS from E. coli. Approximately $10^{5}$ cells were treated with LPS for $24 \mathrm{~h}$ in the presence of $10 \%$ FCS, and IL- $1 \beta$ was quantified in the cell supernatants $(0.1$ $\mathrm{ml}$ ) by radioimmunoassay. Cultured monocytes $\left(20 \mathrm{~h}, 37^{\circ} \mathrm{C}\right)$ did not respond to the LPS stimulus with IL- $1 \beta$ production (triangles; lower two plots depict results obtained with and without PMB). PMB at the given concentration almost totally inhibited the stimulatory action of $1 \mathrm{ng} / \mathrm{ml} \mathrm{LPS}$ on freshly isolated cells. report that showed monocytes to lose their ability to produce IL- $1 \beta$ in response to an LPS stimulus after a culture period of $48 \mathrm{~h}$ (29). Data on the response of monocytes cultured for shorter periods were not presented in that communication.

Depletion of cellular ATP by ECH. The cytocidal effects of ECH could most conveniently be detected and quantified by measurements of cellular ATP. This parameter has previously been applied in the study of ECH action on renal tubular epithelial cells (30). As shown in Fig. $2 A$, nanomolar concentrations of ECH evoked depletion of ATP in monocytes. The same ATP-depleting effects were observed with both freshly isolated and cultured cells, and they were irreversible since no replenishment of ATP-content was observed if cells were further cultured for up to $24 \mathrm{~h}$. By light microscopy, ATP-depleted cells were found to present a swollen appearance and they also stained positively with trypan blue. 50\% ATP-depletion occurred at toxin concentrations of $\sim 250 \mathrm{ng} / \mathrm{ml}$ in the presence of FCS. The kinetics of ATP-depletion were very rapid: $\mathrm{ECH}$ at a dose of $2,000 \mathrm{ng} / \mathrm{ml}$ effected $>90 \%$ depletion within 45 min (Fig. 3). If monocytes were suspended in $10 \%$ autologous serum, the dose-response curves shifted to the right. The extent of this shift varied somewhat dependent on the donor (Fig. $4 \mathrm{~A}$ ). ATP depletion generally commenced at $\sim 250 \mathrm{ng} / \mathrm{ml} \mathrm{ECH}$, and $60-80 \%$ depletion was observed at the highest tested toxin dose of $2,000 \mathrm{ng} / \mathrm{ml}$.

$E C H$ stimulates release of $I L-1 \beta$ from cultured monocytes. Subcytocidal doses of $\mathrm{ECH}$, defined as doses that effected no

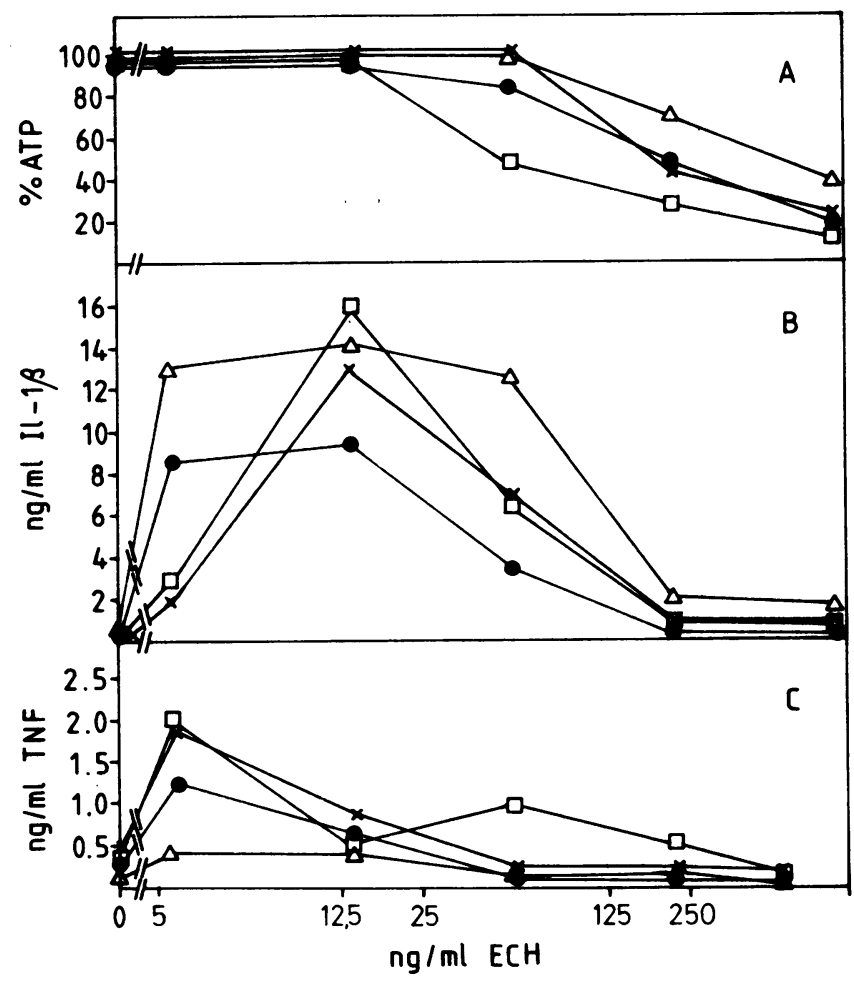

Figure 2. Cytokine-stimulatory action and ATP-depleting effects of ECH on cultured monocytes in the presence of $10 \%$ FCS. $(A)$ Cellular ATP-content, expressed as percent of non-toxin-treated controls. The mean ATP-content in the four controls was $90 \mathrm{pmol} / \mathrm{well}$. ( $B$, $C$ ) Concentrations of IL-1 $\beta$ and TNF in the cell supernatants. The incubation period with $\mathrm{ECH}$ was $6 \mathrm{~h}$ at $37^{\circ} \mathrm{C}$ in the presence of 2 $\mu \mathrm{g} / \mathrm{ml}$ PMB. The plots depict results obtained in four different experiments. 


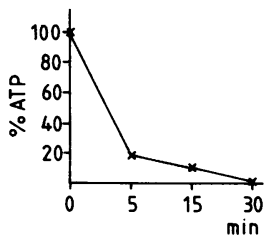

Figure 3. Kinetics of ATP-depletion in cultured monocytes treated with $2,000 \mathrm{ng} / \mathrm{ml}$ $\mathrm{ECH}$ in the presence of FCS and $2 \mu \mathrm{g} / \mathrm{ml}$ PMB. The results were reproduced twice. The $100 \%$ ATP-value in this experiment corresponded to $110 \mathrm{pmol}$ ATP.

or only minimal ATP depletion, evoked release of large amounts of IL- $1 \beta$ by cultured monocytes suspended in FCS (Fig. 2 B). This behavior was noted irrespective of donor, with peak IL- $1 \beta$ concentrations in the range of $10-15 \mathrm{ng} / \mathrm{ml}$ in cell supernatants. These levels were comparable to those found in supernatants of freshly isolated cells stimulated with 1-100 $\mathrm{ng} / \mathrm{ml}$ LPS (28). In all experiments, cells were immersed in medium containing $2 \mu \mathrm{g} / \mathrm{ml}$ PMB immediately before toxin application. That the IL- $1 \beta$ releasing effect of ECH might be due to contaminating LPS was excluded by four findings. First, ECH failed to provoke production of large amounts of TNF- $\alpha$. Levels of this cytokine were generally raised to 1-2 $\mathrm{ng} / \mathrm{ml}$ at subcytocidal toxin concentrations (Fig. $2 C$ ). In contrast, monocytes stimulated with LPS inevitably presented a stronger TNF- $\alpha$-response relative to IL- $1 \beta$ production. Second, $\mathrm{ECH}$ provoked production of IL- $1 \beta$ only in cultured monocytes; freshly isolated cells did not produce substantial amounts of IL- $1 \beta$ at any of the tested toxin concentrations. This response behavior was thus reciprocal to that observed with LPS-stimulation. Third, inactivated toxin preparations that had lost their cytocidal properties failed entirely to stimulate IL- $1 \beta$ production. Fourth, toxin-dependent release of IL- $1 \beta$ in cultured monocytes displayed extremely rapid kinetics, peak levels in cell supernatant approaching maximal values within 1-2 $\mathrm{h}$ after toxin application (Fig. 5). As stated

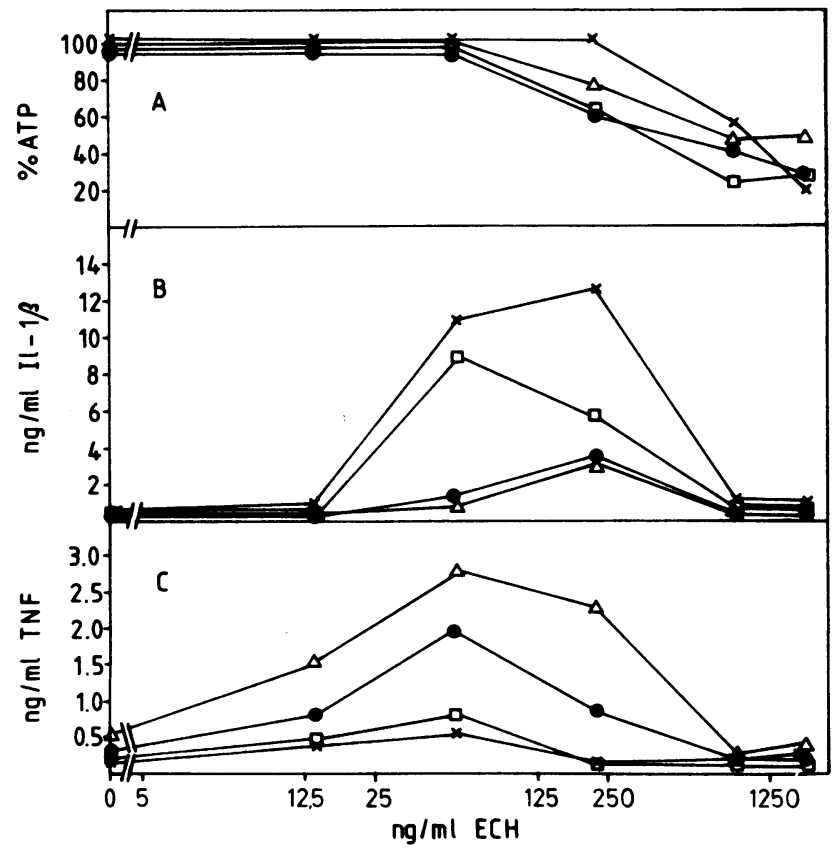

Figure 4. Action of ECH on cultured monocytes in the presence of $10 \%$ autologous serum and $2 \mu \mathrm{g} / \mathrm{ml}$ PMB. Each plot represents data obtained with one individual. There was a marked variation in the IL- $1 \beta$ responses. The mean $100 \%$ ATP-content per well in the four experiments was $100 \mathrm{pmol}$

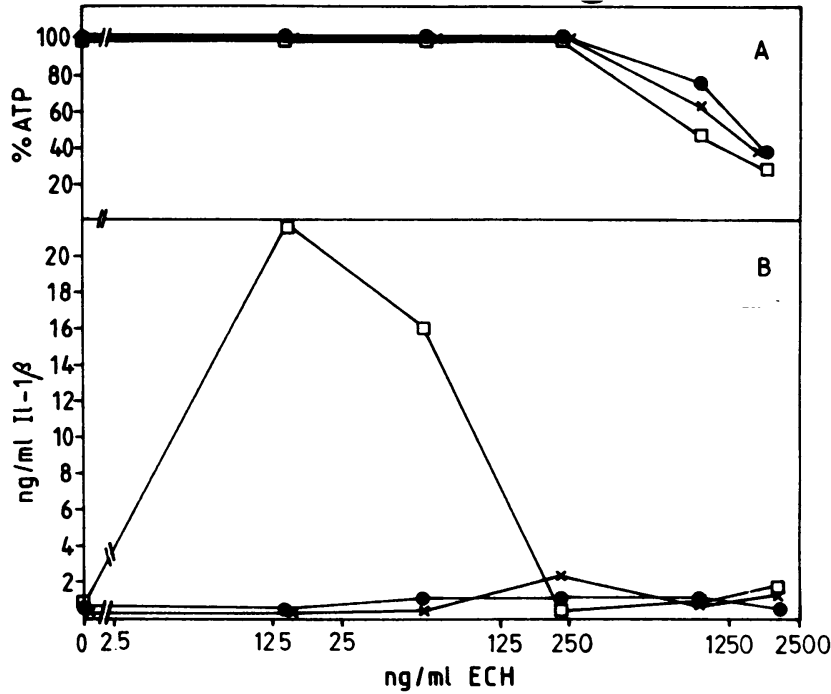

Figure 5. ATP-depletion $(A)$ and IL-1 $\beta$ production $(B)$ in cultured monocytes treated with ECH in the presence of autologous serum (O); IgG-depleted autologous serum (ㅁ); and the latter serum reconstituted with pooled human IgG at an approximately twofold concentration of physiological plasma IgG levels $(x)$. Note the abrogation of the IL- $1 \beta$ response in the presence of $\mathrm{IgG}$, but the lack of protection afforded by the antibodies against attack by higher ATP-depleting toxin doses. A similar set of data was obtained with cells and serum from a second individual. $2 \mu \mathrm{g} / \mathrm{ml}$ PMB was present during all incubations with $\mathrm{ECH}$.

above, no increase in IL- $1 \beta$ levels was observed $2 \mathrm{~h}$ after stimulation with LPS.

If FCS was replaced by autologous serum, an essentially similar response pattern with respect to IL- $1 \beta$ release was noted. However, marked interindividual differences in the peak levels of the cytokine were now encountered (Fig. $4 \mathrm{~B}$ ), with values ranging from 1 to $13 \mathrm{ng} / \mathrm{ml}$. Low and varying levels of TNF- $\alpha$ were also detected (not shown).

It was reasoned that varying antibody titers against $\mathrm{ECH}$ might be responsible for the observed variation in IL- $1 \beta$ release. To test this hypothesis, serum samples from two donors presenting very low or moderate release were depleted of IgG and used in another set of experiments. Indeed, removal of IgG caused the appearance of a uniform, strong IL- $1 \beta$ release with cytokine levels now exceeding $20 \mathrm{ng} / \mathrm{ml}$ (Fig. 6). Upon addition of pooled human IgG to these sera, the IL- $1 \beta$ release returned to minimum levels. A similar suppression was noted if the sera were reconstituted with autologous IgG eluted from

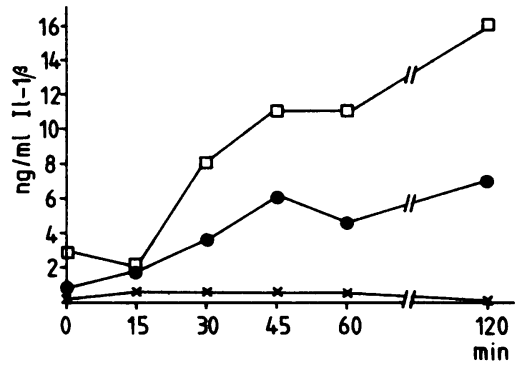

Figure 6. Kinetics of IL- $1 \beta$ release induced by ECH. Cultured monocytes were treated with $0(x), 1.25 \mathrm{ng} / \mathrm{ml}$ (๑) or $2.5 \mathrm{ng} / \mathrm{ml} \mathrm{ECH}$ () in the presence of $10 \% \mathrm{FCS}$ and $2 \mu \mathrm{g} / \mathrm{ml}$ PMB, and the levels of IL- $1 \beta$ quantified in the cell supernatants at the depicted times. Note

the very rapid release of IL- $1 \beta$ induced by the toxin. Similar response patterns were found in two separate experiments. 
the Protein G-Sepharose column (not shown). No consistent alterations in TNF-responses were noted following removal of IgG from NHS.

Preincubation of ECH with human serum for $15 \mathrm{~min}$ at $0^{\circ} \mathrm{C}$ led to complete loss of all ATP-depleting and cytokinestimulatory effects. Hence, neutralizing plasma componeits were efficient if permitted to react with $\mathrm{ECH}$ before confrontation with the sensitive cells occurred. Heat inactivation of ECH $\left(30 \mathrm{~min}, 56^{\circ} \mathrm{C}\right)$ totally destroyed all ATP-depleting and cytokine-releasing properties. The ability to effect membrane insertion and form transmembrane pores thus appeared directly related to the cytokine-releasing action of $\mathrm{ECH}$.

Toxin-dependent $I L-1 \beta$ release does not involve de novo protein synthesis. In a set of control experiments, highly purified, freshly isolated monocytes were stimulated with 0.1 $\mu \mathrm{g} / \mathrm{ml}$ LPS in the presence of actinomycin D or cycloheximide. No IL- $1 \beta$ could be detected in these cell supernates after 6-24 h, confirming that the inhibitors had effectively suppressed de novo production of the cytokine (Fig. $7 \mathrm{~A}$ ). In analogous experiments, highly purified monocytes were first cultured overnight and then immersed in medium containing inhibitor or a combination of both inhibitors for $30 \mathrm{~min}$, after which ECH was applied. In these cases, unaltered or even slightly higher levels of IL- $1 \beta$ were found in the supernatants $($ Fig. $7 \mathrm{~B}$ ). These findings indicated that the toxin affected processing and export of intracellularly accumulated IL- $1 \beta$ precursor, rather than inducing genuine de novo cytokine synthesis.

Attempts were then undertaken to directly show that IL- $1 \beta$ had accumulated in the cultured cells. These were lysed by freeze-thawing in $100 \mu \mathrm{l}$ of medium, and the samples analyzed by radioimmunoassay and ELISA. Lysates of freshly isolated
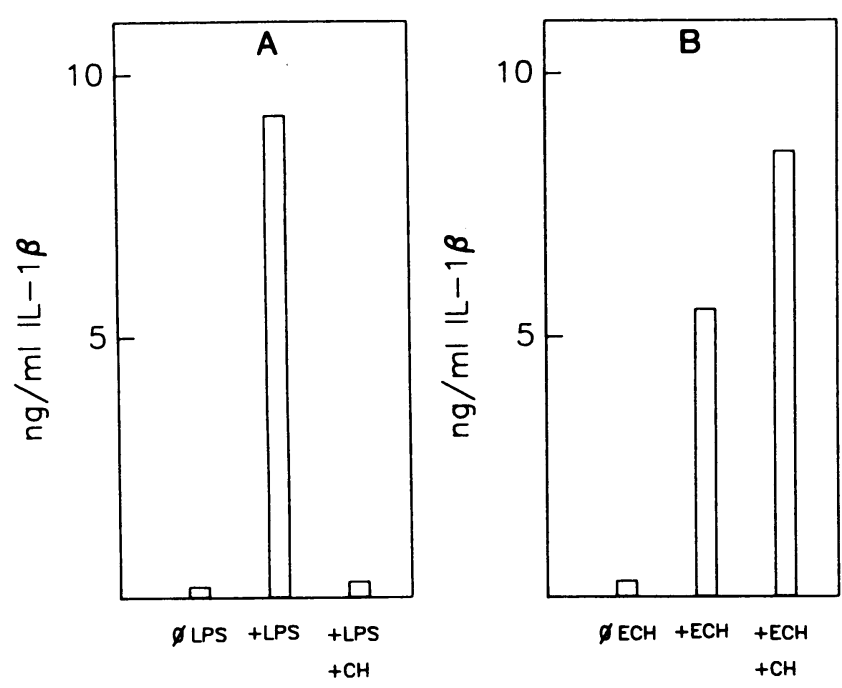

Figure 7. (A) Highly purified monocytes were cultured for $20 \mathrm{~h}$ in medium containing $10 \%$ FCS without LPS, with $100 \mathrm{ng} / \mathrm{ml} \mathrm{LPS}$, or with $100 \mathrm{ng} / \mathrm{ml} \mathrm{LPS}+2 \mu \mathrm{g} / \mathrm{ml}$ cycloheximide $(\mathrm{CH})$. IL- $1 \beta$ was quantified in cell supernatants; $\mathrm{CH}$ fully inhibited the de novo synthesis of the cytokine. $(B)$ Highly purified monocytes were first cultured overnight in $10 \%$ FCS and then treated with $80 \mathrm{ng} / \mathrm{ml} \mathrm{ECH}$ for $6 \mathrm{~h}, 37^{\circ} \mathrm{C}$ in the presence or absence of $2 \mu \mathrm{g} / \mathrm{ml} \mathrm{CH}$. Release of the cytokine occurred despite the presence of the inhibitor. The same results were obtained when ECH was applied in the presence of 10 $\mu \mathrm{g} / \mathrm{ml}$ actinomycin $\mathrm{D}$. cells were found to contain $0.1-0.2 \mathrm{ng} / \mathrm{ml} \mathrm{IL-} 1 \beta$, whereas cells cultured overnight contained $1.5-2.0 \mathrm{ng} / \mathrm{ml} \mathrm{IL-} 1 \beta$, as determined with these assays. Hence, although slight rises in intracellular IL- $1 \beta$ were found after culture, they did not account for the very marked levels of IL- $1 \beta$ (generally above $10 \mathrm{ng} / \mathrm{ml}$ ) recovered in the supernatants of cells after treatment with $\mathrm{ECH}$.

Cytokine-stimulatory and cytocidal action of viable E. coli on monocytes. The next experiments were performed in order to assess the effects evoked upon confrontation of monocytes with viable, toxin-producing bacteria. As shown in Fig. $8 \mathrm{~A}$, incubation of freshly isolated monocytes with each of the four toxin-producing strains led to rapid ATP-depletion within 90 min. An average ratio of only $0.3-3 \mathrm{CFU} /$ monocyte sufficed to cause $\sim 50 \%$ loss of total ATP. At the same time, all toxin-

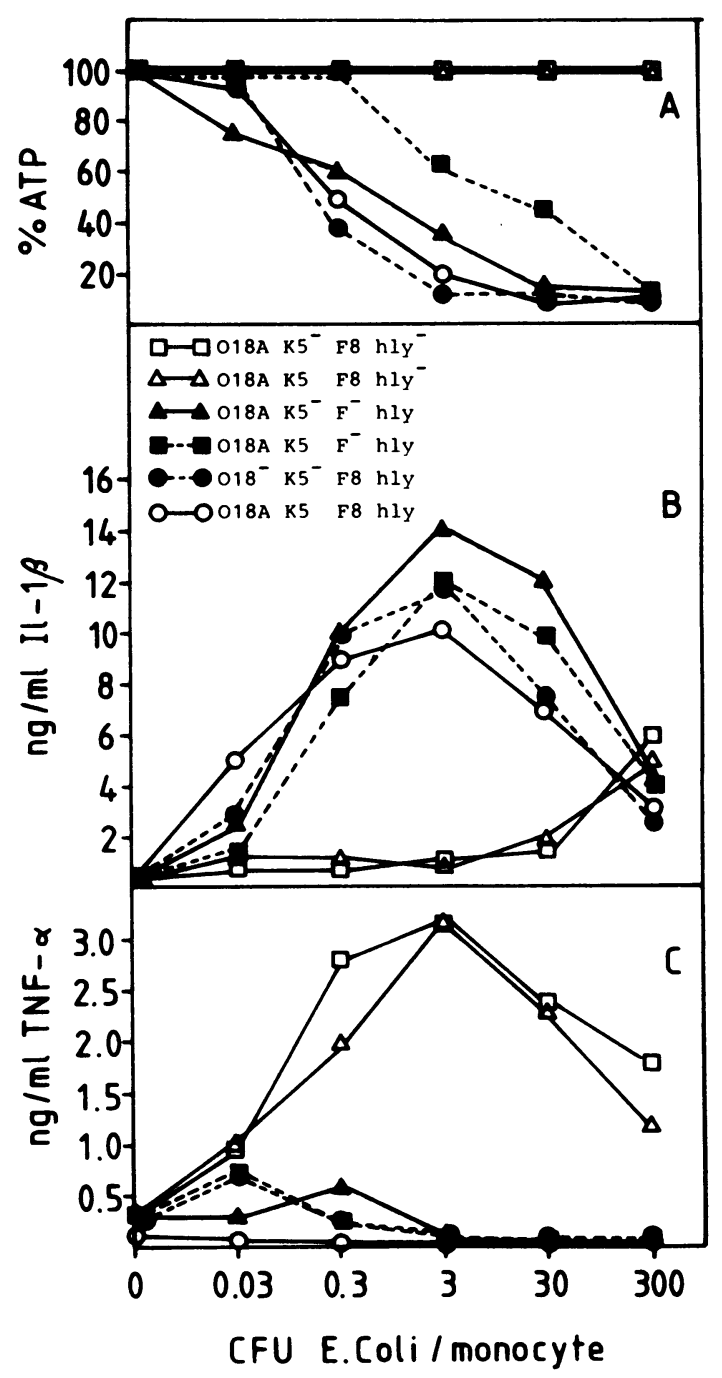

Figure 8. Effects of incubation of viable $E$. coli with freshly isolated human monocytes in the presence of FCS. Six strains were used with the given characteristics and at the given, approximate bacteria to cell ratios. Measurements of cellular ATP $(A)$ and of IL-1 $\beta(B)$ and TNF- $\alpha(C)$ in the cell supernatants were performed after $70 \mathrm{~min}$ incubation at $37^{\circ} \mathrm{C}$. All strains of toxin-producers evoked ATP-depletion and IL- $1 \beta$ production, but depressed TNF-production presumably due to their cytocidal action. The $100 \%$ ATP-content corresponded to $\sim 140$ pmol ATP per well. 
producing strains elicited IL- $1 \beta$ responses which were no longer dissociated from the ATP-depleting effects (Fig. $8 \mathrm{~B}$ ). However, IL-1 responses were reduced at the highest bacteria:cell ratio $(300: 1)$, presumably due to ultra-rapid killing of the monocytes. In contrast, neither of the two nontoxin producers evoked either ATP-depletion or IL-1 production within the incubation period of $90 \mathrm{~min}$.

TNF-responses were measured after $2 \mathrm{~h}$ incubation. As shown in Fig. $8 C$, toxin-dependent cytocidal activity was paralleled by a sharp decrease in TNF-production; hence, there was a clear reciprocity between production of TNF vs. IL- $1 \beta$. Non-toxin producers evoked release of considerable amounts of TNF into the supernatants.

When cultured monocytes $(20 \mathrm{~h})$ from the same donor were used in the same experimental system, the cytocidal activity of hemolytic $E$. coli strains remained comparable, and there was a slightly enhanced IL- $1 \beta$ response compared to freshly isolated cells at all tested bacteria: monocyte ratios. The TNF-response pattern was essentially the same as in Fig. $8 \mathrm{C}$ (data not shown). When cultured monocytes were incubated with toxin-producing bacteria in the presence of actinomycin $D, I L-1 \beta$ release was again registered (peak values: 10-12 $\mathrm{ng} / \mathrm{ml})$.

Synergism between LPS and ECH in the provocation of $I L-1 \beta$ release. All the previous data indicated that $\mathrm{ECH}$ provoked or accelerated release of IL- $1 \beta$ when the cytokine precursor was present in cells. In a final set of experiments, freshly isolated monocytes were incubated with $1 \mu \mathrm{g} / \mathrm{ml} \mathrm{LPS} \mathrm{for} 2 \mathrm{~h}$ in $10 \%$ FCS. Thereafter, one set of cell cultures received ECH, and the controls received medium. After another $2 \mathrm{~h}, \mathrm{IL}-1 \beta$ was quantified in cell supernatants. Whereas the control cells released only small amounts of IL- $1 \beta$ in this time period, cells additionally treated with $\mathrm{ECH}$ liberated large quantities of IL-1 $\beta$ (Fig. 9). Hence, ECH was found to synergize with LPS to effect rapid liberation of IL- $1 \beta$ from primed cells.

\section{Discussion}

This study shows that in addition to PMN, monocytes represent sensitive targets for the cytocidal action of ECH. Subnanomolar concentrations of purified toxin effect rapid, irreversible depletion of cellular ATP, a process that is paralleled by cellular swelling and trypan blue staining positivity. As pre-

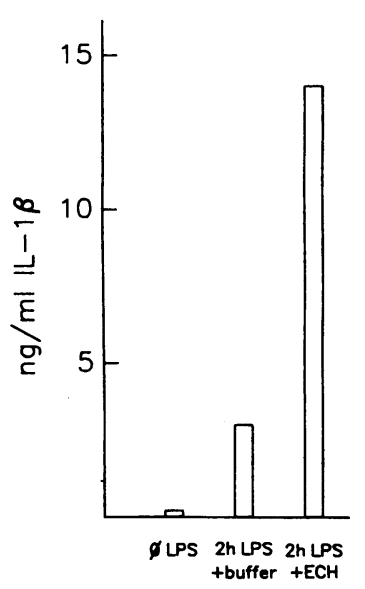

Figure 9. Synergism between LPS and $\mathrm{ECH}$. Monocytes were freshly isolated and incubated for $2 \mathrm{~h}$ in medium without LPS, or in medium containing $1 \mu \mathrm{g} / \mathrm{ml}$ LPS. Thereafter, cells received either buffer of $\mathrm{ECH}$ $(80 \mathrm{ng} / \mathrm{ml}$ ) for another $2 \mathrm{~h}$ (no PMB). Cells cultured in the absence of LPS released little IL-1 $\beta$ (left column); treatment of these cells with ECH also did not lead to cytokine release (not shown). Cells treated with LPS followed by buffer released small amounts of IL-1 $\beta$ in the total $4 \mathrm{~h}$ of culture (central column). Cells treated with LPS followed by ECH released large amounts of IL- $1 \beta$ in the same time period. The results were reproduced twice. viously found for PMN, naturally occurring plasma protein inhibitors are unable to effectively suppress this cytotoxic effect, which we assume is due to formation of transmembrane pores in the target plasma membranes.

A second, novel finding relates to the liberation of large quantities of IL $-1 \beta$ from monocytes attacked by very low doses of ECH. In addition, small quantities of and TNF- $\alpha$ were detected. Since levels of the latter monokine were low, we confined our present studies to a closer analysis of the IL-1 $\beta$ response. Several considerations collectively excluded that this derived from contaminating LPS. First, ECH-dependent IL-1 $\beta$ release was observed only in cultured monocytes. In contrast, LPS induced IL-1 secretion only in freshly isolated cells (29, and this report). Second, the amounts of LPS contaminating the ECH preparations were far below the threshold required for induction of $\mathrm{IL}-1 \beta$ synthesis in the given presence of 2 $\mu \mathrm{g} / \mathrm{ml}$ PMB. In this context, heat-inactivated ECH also failed to provoke liberation of the cytokine. Third, LPS-induced IL- $1 \beta$ secretion was totally abrogated in the presence of actinomycin $D$ or cycloheximide, whereas neither inhibitor suppressed the appearance of IL- $1 \beta$ in the supernatants of ECHtreated cells. Thus, in contrast to LPS, ECH apparently did not stimulate de novo monokine synthesis. By exclusion, toxindependent release of IL- $1 \beta$ must have derived from processing and export of its $31 \mathrm{~K}$ precursor that presumably accumulates intracellularly during cell culture. If correct, this assumption would also explain why ECH failed to induce IL-1 $\beta$ release from freshly isolated cells.

Although experimental data to directly prove the latter hypothesis are not yet available, recent reports indicate that the concept is basically tenable. It is known that LPS first induces accumulation of IL-1 precursors in the cell cytoplasma, processing and export then following in a second, temporally dissociated step (31-33). Secretion of the active 17K IL-1 $\alpha$ and IL- $1 \beta$ molecules probably occurs via a novel mechanism that is currently under investigation (34). Production of both IL-1 $\alpha$ and $\mathrm{IL}-1 \beta 31 \mathrm{~K}$ precursors is apparently triggered when cells become adherent and during short-term culture, whereby the cytokines remain predominantly cell-associated (35-38). Cellbound IL-1 has previously been quantified mainly with the use of bioassays. Since only the precursor of IL-1 $\alpha$ binds to the IL-1 receptor, such assays may not have detected the IL-1 $\beta$ precursor (39). In this connection, our inability to measure significant levels of cell-associated IL- $1 \beta$ by radioassay and ELISA could indicate that the IL-1 $\beta$ precursor is also poorly reactive in the commercial immunoassays. Clearly, there is presently a demand for reliable assays to quantify the IL- $1 \beta$ precursor.

When experiments were conducted with genetically related strains of $E$. coli, toxin producers were found to exhibit a truly remarkable cytocidal potency that was independent of cellular factors including capsule, $\mathrm{O}$-antigen and $\mathrm{P}$-fimbriae. Confrontation of freshly isolated monocytes with very low numbers of toxin-producing bacteria resulted in rapid release of large amounts of IL-1 $\beta$. These findings would be compatible with the concept that very small amounts of $\mathrm{ECH}$ produced by viable bacteria provoke rapid processing and release of intracellular IL-1 $\beta$, the production of which can be due both to LPS-stimulation (in freshly isolated monocytes) and to cell cultivation. The notion that ECH can synergize with LPS in evoking IL- $1 \beta$ release was subsequently directly corroborated (Fig. 9). 
The mechanisms responsible for IL-1 release from ECHtreated cells await clarification. High toxin doses applied either as isolated protein or as dense bacterial suspensions led to a decrease in measurable IL- $1 \beta$. Therefore, IL- $1 \beta$ export may be unable to occur if cells are rapidly killed. At the same time, these results speak against simple leakage of intracellular IL- $1 \beta$ through toxin pores. According to previous estimates, such pores would indeed be too small to permit passage of such a large molecule (11-13). Possibly, low and subcytocidal doses of ECH transiently generate a few transmembrane pores, permitting ion fluxes to take place that may be important in triggering the export machinery. IgG antibodies appear to be able to suppress the action of such low toxin doses and they may thus exert beneficial, protective effects in this regard.

The possibility that lymphocytes contaminating the monocyte preparations released lymphokines in response to attack by $\mathrm{ECH}$, this in turn stimulating IL- $1 \beta$ production and liberation, appears highly unlikely. First, IL- $1 \beta$ release from cultured monocytes occurred in the presence of cycloheximide and actinomycin $D$, which should have effectively suppressed production of lymphokines (IL-2 or GM-CSF) by lymphocytes. Second, the kinetics of IL-1 $\beta$ release were very rapid even in the presence of these inhibitors; it is improbable that a time span of only 60 min would suffice not only to stimulate lymphokine production but also for these lymphokines to act on the monocytes. Finally, IL- $1 \beta$ release was also noted in experiments using very pure preparations of monocytes (Fig. 7).

The possibility may further be considered that the failure of freshly isolated monocytes to secrete IL- $1 \beta$ in response to $\mathrm{ECH}$ was due to $I L-1 \beta$ release during cell isolation, followed by unresponsive of the cells to stimuli for a few hours thereafter. However, this appears highly unlikely because monocytes isolated in our experiments readily responded to LPS stimulation (Fig. 1). Furthermore, freshly isolated monocytes also rapidly produced and released IL- $1 \beta$ when they were confronted with viable, toxin-producing $E$. coli (Fig. 8).

In sum, hemolytic $E$. coli are endowed with a remarkable capacity to kill both polymorphonuclear and mononuclear phagocytes. Toxin production paired with serum resistance thus provides the micro-organisms with uniquely effective mechanisms for counteracting major components of the host immune defence system. The cytocidal action of $\mathrm{ECH}$ may extend to several other cell types including endothelial cells (40) and renal tubular epithelial cells (30). Confrontation of monocytes with just a few bacteria will result in rapid production and release of IL-1 $\beta$. Cells previously primed to synthesize IL-1 $\beta$ precursor will probably be induced to release their content of the cytokine. It is possible that other biologically active polypeptides sharing the same pathway of secretion are liberated simultaneously. In view of the known local and systemic effects of IL-1 $(41,42)$, and its synergism with TNF $(43,44)$, such processes are probably relevant to the pathogenesis of disease caused by hemolytic strains of $E$. coli and other medically important Enterobacteriaceae that produce functionally related cytolysins.

\section{Acknowledgments}

We thank I. B. Holland for providing E. coli strain LE 2001.

This study was supported by the Deutsche Forschungsgemeinschaft (SFB 249, Teilprojekt A5) and the Verband der Chemischen Industrie.

\section{References}

1. Cavalieri, S. J., G. A. Bohach, and I. S. Snyder. 1984. Escherichia coli $\alpha$-hemolysin: characteristics and probable role in pathogenicity. Microbiol. Rev. 48:326-343.

2. Cooke, E. M., and S. P. Ewins. 1975. Properties of strains of Escherichia coli isolated from a variety of sources. J. Med. Microbiol. 8:107-111.

3. Minshew, B. H., J. Jorgensen, G. W. Counts, and S. Falkow. 1978. Association of hemolysin production, hemagglutination of human erythrocytes, and virulence for chicken embryos of extraintestinal Escherichia coli isolates. Infect. Immun. 20:50-54.

4. Brooks, H. J. L., F. O Grady, M. A. McSherry and W. R. Cattell. 1980. Uropathogenic properties of Escherichia coli in recurrent urinary tract infection. J. Med. Microbiol. 13:57-68.

5. Deboy, J. M., I. K. Wachsmuth, and B. R. Davis. 1980. Hemolytic activity in enterotoxigenic and non-enterotoxigenic strains of Escherichia coli. J. Clin. Microbiol. 12:836-840.

6. Evans, D. J., Jr., D. G. Evans, C. Hohne, M. A. Noble, E. V. Haldane, H. Lior, and L. S. Young. 1981. Hemolysin and K antigens in relation to serotype and hemagglutination type of Escherichia coli isolated from extraintestinal infections. J. Clin. Microbiol. 13:171178.

7. Hughes, C., J. Hacker, A. Roberts, and W. Goebel. 1983. Hemolysin production as a virulence marker in symptomatic and asymptomatic urinary tract infections caused by Escherichia coli. Infect. Immun. 39:546-551.

8. Welch, R. A., E. P. Dellinger, B. Minshew, and S. Falkow. 1981. Haemolysin contributes to virulence of extra-intestinal E. coli infections. Nature (Lond.). 294:665-667.

9. Waalwijk, C., J. F. van den Bosch, D. M. MacLaren, and J. de Graaff. 1982. Hemolysin plasmid coding for the virulence of a nephropathogenic Escherichia coli strain. Infect. Immun. 35:32-37.

10. Hacker, J., C. Hughes, H. Hof, and W. Goebel. 1983. Cloned hemolysin genes from Escherichia coli that cause urinary tract infection determine different levels of toxicity in mice. Infect. Immun. 42:57-63.

11. Bhakdi, S., N. Mackman, J. M. Nicaud, and I. B. Holland. 1986. E. coli hemolysin may damage target cell membranes by generating transmembrane pores. Infect. Immun. 52:63-69.

12. Menestrina, G., N. Mackman, I. B. Holland, and S. Bhakdi. 1987. E. coli hemolysin forms voltage-dependent ion channels in lipid membranes. Biochim. Biophys. Acta. 905:109-117.

13. Menestrina, G. 1988. Escherichia coli hemolysin permeabilizes small unilamellar vesicles loaded with calcein by a single-hit mechanism. FEBS (Fed. Eur. Biochem. Soc.) Lett. 232:217-220.

14. Bhakdi, S., and J. Tranum-Jensen. 1987. Damage to mammalian cells by proteins that form transmembrane pores. Rev. Physiol. Biochem. Pharmacol. 107:148-223.

15. Felmlee, T., S. Pellet, and R. Welch. 1985. Nucleotide sequence of an Escherichia coli chromosomal hemolysin. J. Bacteriol. 163:94105.

16. Strathdee, C. A., and R. Y. Lo. 1987. Extensive homology between the leukotoxin of Pasteurella haemolysin Al and the alphahemolysin of Escherichia coli. Infect. Immun. 55:3233-3236.

17. Koronakis, V., M. Cross, B. Senior, E. Koronakis, and C. Hughes. 1987. The secreted hemolysins of Proteus mirabilis, Proteus vulgaris and Morganella morganii are genetically related to each other and to the alpha-hemolysin of Escherichia coli. J. Bacteriol. 169:1509-1515.

18. Lo, R. Y. C., C. A. Strathdee, and P. E. Shewen. 1987. Nucleotide sequence of the leukotoxin genes of Pasteurella haemolytica A1. Infect. Immun. 55:1987-1996.

19. Bhakdi, S., M. Muhly, U. Mannhardt, F. Hugo, K. Klapettek, C. Mueller-Eckhardt, and L. Roka. 1988. Staphylococcal $\alpha$-toxin promotes blood coagulation via attack on human platelets. J. Exp. Med. 168:527-543.

20. Bhakdi, S., S. Greulich, M. Muhly, B. Eberspächer, H. Becker, 
A. Thiele, and F. Hugo. 1989. Potent leukocidal action of Escherichia coli hemolysin mediated by permeabilization of target cell membranes. J. Exp. Med. 169:737-754.

21. Gadeberg, O. V., and I. Orskov. 1983. Cytotoxic effect of an alpha-hemolytic Escherichia coli strain on human blood monocytes and granulocytes in vitro. Infect. Immun. 41:358-364.

22. Cavalier, S. J., and I. S. Snyder. 1982. Cytotoxic activity of partially purified Escherichia coli alpha-haemolysin. J. Med. Microbiol. 15:11-21.

23. Mackman, N., and I. B. Holland. 1984. Functional characterization of a cloned hemolysin determinant from $E$. coli of human origin, encoding information for the secretion of a $107 \mathrm{~K}$ polypeptide. Mol. Gen. Genet. 196:129-134.

24. Mackman, N., J. M. Nicaud, L. Gray, and I. B. Holland. 1986. Secretion of hemolysin by E. coli. Curr. Top. Microbiol. Immunol. 125:159-181.

25. Wevers, P., R. Picken, G. Schmidt, B. Jann, K. Jann, J. R. Golecki, and M. Kist. 1980. Characterization of pili associated with Escherichia coli 018ac. Infect. Immun. 29:685-691.

26. Gupta, D. S., B. Jann, G. Schmidt, J. R. Golecki, I. Orskov, F. Orskov, and K. Jann. 1982. Coliphage K5, specific for $E$. coli exhibiting the capsular K5 antigen. FEMS (Fed. Eur. Microbiol. Soc.) Microbiol. Lett. 14:75-78.

27. Blumenstock, E., and K. Jann. 1982. Adhesion of piliated Esch erichia coli strains to phagocytes: differences between bacteria with mannose-sensitive pili and those with mannose-resistant pili. Infect. Immun. 35:264-269.

28. Lisi, P. T., C.-W. Chu, G. A. Koch, S. Endres, G. Lonnemann, and C. A. Dinarello. 1987. Development and use of a radioimmunoassay for human interleukin-1 $\beta$. Lymphokine Res. 6:229-244.

29. Burchett, S. K., W. M. Weaver, J. A. Westall, A. Larsen, S Kronheim, and C. B. Wilson. 1988. Regulation of tumor necrosis factor/cachectin and IL-1 secretion in human mononuclear phagocytes. J. Immunol. 140:3473-3481.

30. Keane, W. F., R. Welch, G. Gekker, and P. K. Peterson. 1987 Mechanism of Escherichia coli $\alpha$-hemolysin induced injury to isolated renal tubular cells. Am. J. Pathol. 126:350-357.

31. Dinarello, C. A. 1989. Interleukin-1 and its biologically related cytokines. Adv. Immunol. 44:153-205.

32. Matsushima, K., M. Taguchi, E. J. Kovacs, H. A. Young, and J. J. Oppenheim. 1986. Intracellular localization of human monocyte associated interleukin-1 (IL-1) activity and release of biologically active IL-1 from monocytes by trypsin and plasmin. J. Immunol. 136:2883-2891.
33. Lew, W., J. J. Oppenheim, and K. Matsushima. 1988. Analysis of the suppression of IL- $\alpha$ and IL- $1 \beta$ production in human peripheral blood mononuclear adherent cells by a glucocorticoid hormone. $J$. Immunol. 140:1895-1902.

34. Singer, I. I., S. Scott, G. L. Hall, G. Limjuco, J. Chin, and J. A. Schmidt. 1988. Interleukin- $1 \beta$ is localized in the cytoplasmic ground substance but is largely absent from the Golgi apparatus and plasma membranes of stimulated human monocytes. J. Exp. Med. 167:389407.

35. Giri, J. G., P. T. Lomedico, and S. B. Mizel. 1985. Studies on the synthesis and secretion of interleukin-1. A 33,000 molecular weight precursor for interleukin-1. J. Immunol. 134:343-349.

36. Bayne, E. K., E. A. Rupp, G. Limjuco, J. Chin, and J. A. Schmidt. 1986. Immunocytochemical detection of interleukin-1 within stimulated human monocytes. J. Exp. Med. 163:1267-1280.

37. Bakouche, O., D. C. Brown, and L. B. Lachman. 1987. Subcellular localization of human monocyte interleukin-1: evidence for an inactive precursor molecule and a possible mechanism for IL-1 release. J. Immunol. 138:4249-4255.

38. Couturier, C., N. Haeffner-Cavaillion, L. Weiss, E. Fischer, and M. D. Kazatchkine. 1990. Induction of cell-associated IL-1 through stimulation of the adhesion-promoting proteins LFAl (CD1 la/CD18) and CR3 (CD1 1b/CD18) of human monocytes. Eur. J. Immunol. In press.

39. Mosley, B., D. L. Ordal, K. S. Prickett, A. Larsen, D. Cosman, P. J. Conlon, S. Gillis, and S. K. Dower. 1987. The interleukin-1 receptor binds the human interleukin- $1 \alpha$ precursor but not the interleukin-1 $\beta$ precursor. J. Biol. Chem. 262:2941-2944.

40. Seeger, W., H. Walter, N. Suttorp, M. Muhly, and S. Bhakdi. 1989. Thromboxane-mediated hypertension and vascular leakage evoked by low doses of Escherichia coli hemolysin in rabbit lungs. $J$. Clin. Invest. 84:220-227.

41. Dinarello, C. A. 1984. Interleukin-1. Rev. Infect. Dis. 6:51-95.

42. Dinarello, C. A. 1985. An update on human interleukin-1: from molecular biology to clinical relevance. J. Clin. Immunol. 5:287-297.

43. Nawroth, P. P., I. Bank, D. Handley, J. Cassimeris, L. Chess, and D. Stern. 1986. Tumor necrosis factor/cachectin interacts with endothelial cell receptors to induce release of interleukin-1. J. Exp. Med. 163:1363-1675.

44. Flores, E. A., B. R. Bistrian, J. J. Pomposelli, C. A. Dinarello, G. L. Blackburn, and N. W. Istfan. 1989. Infusion of tumor necrosis factor/cachectin promotes muscle catabolism in the rat. J. Clin. Invest. 83:1614-1622. 